\title{
Pengaruh Kepemilikan Manajerial, Risiko Litigasi dan Leverage terhadap Konservatisme Akuntansi dengan Financial Distress sebagai Variabel Moderating
}

\author{
Elvi Rahmi ${ }^{1}$, Niswah Baroroh ${ }^{2}$ \\ Universitas Negeri Semarang ${ }^{1,2}$ \\ rahmielvi902@gmail.com¹,barorohniswah@gmail.com²
}

*Penulis korespondensi

Diajukan : 20 Januari 2022

Disetujui : 3 Februari 2022

Dipublikasi : 4 Februari 2022

\begin{abstract}
Accounting conservatism is an attitude of prudence in responding to uncertainties in the future by recognizing expenses and liabilities as soon as possible, but only recognizing income and assets when they are sure they will be received. Accounting conservatism in Indonesia is still very low. There are still some companies that have not applied the accounting conservatism method. In this study, the purpose is to investigate the influence of management ownership, litigation risk, and leverage on accounting conservatism using financial distress as the moderating variable. The population was picked as many as 26 manufacturing enterprises listed on the Indonesia Stock Exchange (IDX) in the 2018-2020 timeframe, and 72 samples were gathered by purposive sampling approach. Descriptive analysis and regression analysis were utilized to assess the data via a moderating test of the difference in absolute values. The findings demonstrate that management ownership and litigation risk do not have a considerable influence, whereas leverage has a big impact on accounting conservatism. Financial distress is not able to moderate considerably in order to affect the three factors on accounting conservatism. Therefore, additional study is required to broaden the factors so that the findings obtained are more correct. Suggestions from this study, the company is expected to improve the principle of accounting conservatism to reduce the asymmetry between shareholders or investors and creditors.
\end{abstract}

Keywords: accounting conservatism, financial distress, litigation risk, leverage, and managerial ownership.

\section{PENDAHULUAN}

Tantangan dalam penyajian laporan keuangan yakni konservatisme yang dimaknai sebagai konsep penuh pertimbangan guna menyampaikan informasi finansial yang berkualitas tinggi. Umumya, konsep tersebut diterapkan sebagai aturan guna merespon anggaran dan kerugian, omset/ keuntungan yang melambat, mengkuantifikasi valuasi aset dengan ukuran minimum, dan mengevaluasi kewajiban dengan ukuran maksimum (Savitri, 2016). Apabila terdapat skenario yang berpotensi mengakibatkan kerugian, anggaran 
berlebihan, dan pelanggaran kewajiban, maka dampak tersebut sangat substansial bagi keberlangsungan bisnis. Namun sebaliknya, kondisi yang memberikan potensi keuntungan, peningkatan omset, dan pertumbuhan valuasi aset tidak secara langsung diketahui hingga dilakukan audit guna menganalisis permasalahan yang sebenarnya terjadi (Pratanda \& Kusmuriyanto, 2014).

Dewasa ini, kasus permasalahan finansial di Indonesia masih banyak ditemukan. Misalnya , kasus overstate laporan keuangan yang membawa nama perusahaan plat merah seperti PT Kimia Farma (Persero) Tbk akibat pelanggaran dalam penggunaan alat rapid test bekas sesuai laporan pada 27 April 2021. Sebelumnya di 2020, perusahan tersebut membukukan laba sebesar Rp. 17,63 miliar, dibandingkan pada tahun 2019 yang rugi sebanyak Rp. 12,72 miliar. Selain itu, terdapat kasus lain yang membawa nama PT Thosiba teridentifikasi melakukan accounting fraud sebanyak US\$ 1,22 miliar (www.liputan6.com).

Terdapat beberapa studi yang telah dilakukan guna menganalisis faktor-faktor yang berdampak pada konservatisme. Namun, pengkajian mengenai dampak dari kepemilikan manajerial terhadap konservatisme masih teridentifikasi adanya kesenjangan penelitian. Misalnya, Dewi \& Suryanawa (2014) dan Nugroho (2012) yang menyatakan bahwa kepemilikan manajerial memiliki dampak positif terhadap konservatisme akuntansi. Menurut Brilianti (2013); Deviyanti (2012); dan Sugiarto (2017) menjabarkan bahwa terdapat dampak negatif dari korelasi antara kepemilikan manajerial dan konservatisme akuntansi. Selain itu, Inung et al. (2020) dan Sinambela \& Almilia (2018) menjelaskan bahwa kepemilikan manajerial tidak berdampak substansial pada prinsip konservatisme akuntansi.

Studi mengenai risiko litigasi mempunyai perbedaan dari variabel sebelumnya. Nugroho (2012) dan Zuhriyah (2014) menginterpretasikan bahwa risiko litigasi memiliki dampak positif pada konservatisme akuntansi. Sebaliknya, Dewi et al. (2014) dan Mustikasari et al. (2020) mengungkapkan bahwa risiko litigasi berdampak negatif pada konservatisme akuntansi. Sedangkan Maulana (2017); Putri (2017); dan Sinambela \& Almilia (2018) menyimpulkan bahwa risiko litigasi tidak berdampak substansial pada konservatisme akuntansi.

Studi mengenai korelasi leverage dengan konservatisme akuntansi teridentifikasi adanya kesenjangan riset. Misalnya, Deviyanti (2012); Inung et al. (2020); dan Sugiarto (2017) mengungkapkan bahwa leverage berdampak positif pada konservatisme akuntansi. Sebaliknya, Dewi et al. (2014); Maulana (2017), Noviantari \& Ratnadi (2015); dan Putri (2017) menunjukan bahwa leverage berdampak negatif pada konservatisme akuntansi. Namun, Brilianti (2013); dan Putri et al. (2020) mengutarakan bahwa leverage tidak memiliki dampak yang substansial pada konservatisme akuntansi.

Dengan demikian, atas dasar kesenjangan riset dan inkonsistensi konklusi dari studi-studi sebelumnya, maka penulis meneliti mengenai korelasi dari variabel-variabel yang memiliki dampak pada konservatisme akuntansi melalui substitusi variabel lain seperti financial distress sebagai variabel moderasinya. Pemilihan variabel independen seperti kepemilikan manajerial, risiko litigasi dan leverage dipertimbangkan karena ketiga variable tersebut diproyeksikan mempunyai dampak yang substansial terhadap konservatisme akuntansi sebagai variabel dependen. Objek riset ini yakni mengobservasi perusahaan manufaktur yang teregistrasi di Bursa Efek Indonesia (BEI) untuk periode 2018-2020. 


\section{Teori Keagenan}

\section{STUDI LITERATUR}

Menurut Jensen \& Meckling (1976); dan Kholmi et al., (2010), teori keagenan didefiniskan sebagai korelasi antara pemilik dengan manajemen atas dasar kesepakatan kontrak guna memberikan wewenang untuk pengambilan keputusan. Hubungan kedua pihak tersebut memberikan dampak dan risiko untuk saling menanamkan kepercayaan atas dasar kesepakatan. Pemberian kewenangan oleh pihak manajemen memiliki rasa tanggung jawab kepada pemilik atas segala keputusan yang diambil. Namun, tantangan terbesar dalam penerapan teori tersebut yaitu apabila terdapat keputusan atau kepentingan yang kontradiktif (Pugna \& Duţescu, 2020).

Selain itu, pihak manajemen tidak akan selalu memberikan semua fakta/ data kepada pihak pemegang saham. Menurut Sholikhah (2020) bahwa adanya asimetri informasi berdampak pada kurangnya kepercayaan pemegang saham terhadap perusahaan. Oleh sebab itu, hubungan kepercayaan antara kedua belah pihak perlu diharmonisasi melalui implementasi prinsip konservatisme akuntansi agar dapat dimanfaatkan guna menurunkan biaya agensi, mengurangi asimetri informasi, penyalahgunaan wewenang, serta membatasi pihak tertentu untuk memverifikasi informasi yang bersifat pribadi (Mohammed et al., 2017).

\section{Teori Akuntansi Positif}

Watts \& Zimmerman (1990) mendefinisikan teori akuntasi positif sebagai konsep yang menjelaskan mengenai faktor-faktor upaya bisnis seperti permasalahan pembukuan terkait finansial, strategi guna mengoptimalkan keuntungan, dan mengestimasi pemilihan akuntansi pada situasi tertentu. Teori tersebut menguraikan bahwa pihak manajemen (direksi) harus memiliki motivasi guna memformulasikan pengambilan keputusan atas dasar data yang bermanfaat bagi kelangsungan bisnis perusahaan. Karena upaya tersebut berdampak pada keberminatan investor untuk menanamkan modalnya, sehingga berbanding lurus juga dengan pertumbuhan perusahaan (Nugroho, 2012). Selain itu, (Riahi \& Belkaoui, 2001) menjabarkan bahwa penerapan teori tersebut mengupayakan agar antar pihak untuk saling bekerjasama guna menumbuhkan operasional bisnis sehingga berdampak pada dividen maupun capital gain yang didapatkan, serta kompensasi sebagai wujud mensejahterakan antar pihak. Terdapat 3 jenis hipotesis dalam teori tersebut yakni: 1) rencana bonus, utang ekuitas, dan biaya politis.I

\section{Konservatisme Akuntansi}

Menurut Financial Accounting Standard Board (FASB) dalam Concept Statement No. 2, konservatisme dimaknai sebagai tindakan yang berprinsip pada penuh pertimbangan dan perhitungan guna menghadapi ketidakpastian bisnis melalui manajemen risiko yang terkalkulasi. Pramudita (2012) dan Savitri (2016) menjelaskan bahwa prinsip tersebut sebagai ejawantah dari perencanaan matang guna menghadapi ketidakstabilan bisnis baik secara beban utang, valuasi aset, hak dan kewajiban, serta kalkulasi omset yang terukur.

\section{Kepemilikan Manajerial}

Kepemilikan manajerial dalam suatu perusahaan dinyatakan sebagai total proporsi kepemilikan modal berupa saham terhadap total modal saham yang dikuasai oleh pihak eksternal (Deviyanti, 2012). Karena adanya dominasi kepemilikan saham, maka secara struktural pemegang saham berkontribusi pada setiap keputusan yang diambil melalui pertimbangan yang matang guna diformulasikan dalam bentuk kebijakan perusahaan. 
Selain itu, setiap kebijakan yang disepakati oleh pihak berkepentingan harus dilakukan dalam rangka meningkatkan nilai perusahaan sehingga terefleksi pada kepercayaan investor untuk menanamkan modalnya (Nugroho, 2012).

\section{Risiko Litigasi}

Risiko litigasi dipahami sebagai bentuk risiko bisnis yang berkaitan dengan hukum (Sinambela \& Almilia, 2018). Risiko tersebut menjadi bagian dari bisnis yang memungkinkan munculnya tuntutan-tuntutan yang melibatkan hukum dari pihak-pihak yang tidak puas dengan kepentingan bisnis seperti regulator investor, maupun kreditur (Nugroho, 2012). Menurut Maulana (2017), contoh kasus litigasi dari perspektif kreditur yakni ketika korporasi gagal memenuhi kewajibannya berdasarkan kontrak untuk membayar utang yang disepakati, maka kreditur akan menggugatnya ke meja hukum. Sedangkan dari pihak investor, kemungkinan terjadinya gugatan karena disebabkan oleh kegiatan perusahaan yang merugikan investor melalui refleksi fluktuasi harga dan volume saham.

\section{Leverage}

Leverage didefinisikan sebagai rasio utang terhadap modal guna mendanai aset bisnis. Pihak manajemen dalam mencari pendanaan melalui mekanisme utang akan mempertimbangkan rasio tersebut, sehingga antara manajer dengan kreditor memutuskan atas kesepakatan kedua belah pihak (Deviyanti, 2012). Selain itu, rasio tersebut dikenal juga sebagai rasio solvabilitas yang dimanfaatkan guna menentukan kapasitas bisnis untuk memenuhi komitmennya dalam membayar utang jangka panjang apabila terjadi likuidasi. Dengan demikian, perusahaan yang tidak berkelanjutan yaitu apabila total utangnya melebihi seluruh valuasi asetnya (Saputra, 2016).

Menurut Pramudita (2012), leverage mengacu pada penggunaan dana yang berasal dari pinjaman guna meningkatkan peluang pendapatan bisnis, dan mengevaluasi kapasitas perusahaan. (Putri, 2017) menjelaskan bahwa penggunaan utang yang berlebihan (utang ekstrim) akan berdampak pada keberlanjutan bisnis sehingga perusahaan terjebak dalam ketidakmampuan melunasi pinjaman tersebut.

\section{Financial Distress}

Pailit atau bangkrut menjadi tantangan besar bagi perusahaan untuk tetap eksis beroperasi. Namun, hal tersebut dapat dicegah melalui mitigasi yang akurat dengan menganalisis dan memperkirakan penyebab kebangkrutan melalui penilaian parameter finansial distress (Firmasari, 2016). Parameter tersebut bermanfaat guna menganalisis dan memitigasi sebagai tanda peringatan dini kebangkrutan sebagai akibat dari posisi keuangan perusahaan yang memburuk (Sulastri \& Anna, 2018). Dampak dari hal tersebut yakni keputusan pihak pemegang saham untuk mengganti manajemen perusahaan sehingga kredibilitas manajemen yang diganti tersebut juga menurun di pasar tenaga kerja (Pramudita, 2012).

\section{Pengaruh Kepemilikan Manajarial terhadap Konservatisme Akuntansi}

Karena struktur kepemilikan manajerial yang kuat dan fundamental dibandingkan dengan pihak eksternal, maka bisnis umunya mengadopsi prosedur akuntansi yang konservatif. Hal tersebut berdampak pada keputusan strategis dari pihak manajemen yang tidak hanya sekedar mengejar keuntungan, tetapi juga memastikan ekspansi dan pertumbuhan perusahaan dapat berkelanjutan. Oleh sebab itu, apabila prosedur tersebut 
diimplementasikan, maka kehati-hatian dalam mengelola perusahaan berdampak pada pengalokasian cadangan modal yang cukup besar untuk rencana ekspansi bisnis (Deviyanti, 2012). Menurut Nugroho (2012) dan Dewi \& Suryanawa (2014), variabel kepemilikan manajerial meiliki dampak positif dan fundamental pada penerapan konservatisme akuntansi. Dengan demikian, hipotesis yang dapat diformulasikan yakni:

$\mathrm{H}_{1}$ : Kepemilikan manajerial berdampak substansial pada konservatisme akuntansi.

\section{Pengaruh Risiko Litigasi terhadap Konservatisme Akuntansi}

Pada ekosistem hukum yang ketat, pihak manajemen cenderung melaporkan keuangan secara konservatif, karena berkorelasi dengan regulasi yang mengatur tentang akuntansi untuk diaudit. Menurut Zuhriyah (2014), risiko litigasi dapat timbul akibat dari klaim kreditur apabila pihak manajemen perusahaan gagal untuk melunasi utang sesuai persyaratannya. Selain itu, ketidakmampuan dalam membayar utang berdampak pada tuntutan dari pihak kreditur ke ranah hukum sehingga menimbulkan pembengkakkan biaya untuk menangani proses tersebut. Oleh sebab itu, pihak manajemen lebih memilih untuk melaporkan kuntungan secara konservatif, karena penyampaian pendapatan yang terlalu tinggi dapat menyebabkan komplikasi hukum. Nugroho (2012) dan Zuhriyah (2014) mengungkapkan bahwa variabel risiko litigasi berdampak positif dan substansial pada penerapan konservatisme akuntansi. Oleh karena itu, hipotesis yang dapat diformulasikan yakni:

$\mathrm{H}_{2}$ : variabel risiko litigasi berdampak substansial pada konservatisme akuntansi.

\section{Pengaruh Leverage terhadap Konservatisme Akuntansi}

Tingginya risiko finansial bisnis dan pihak kreditur berbanding lurus dengan tingginya rasio leverage. Tingginya jumlah utang yang ditanggung perusahaan akan menstimulus pihak menajemen untuk mengelolanya secara bijak, karena terdapat risiko besar bagi keberlangsungan bisnis sehingga pihak kreditur akan memiliki hak yang lebih kuat untuk memantau dan mengetahui kegiatan operasional dan akuntansi perusahaan (Pramudita, 2012). Menurut Deviyanti (2012); Inung et al. (2020); dan Sugiarto (2017), variabel leverage memiliki dampak yang signifikan pada konservatisme akuntansi. Dengan demikian, hipotesis yang dapat diformulasikan yakni:

$\mathrm{H}_{3}$ : variabel leverage berdampak substansial pada konservatisme akuntansi.

\section{Financial Distress Memoderasi Pengaruh Kepemilikan Manajerial terhadap Konservatisme Akuntansi}

Kualitas manajemen perusahaan dapat dievaluasi dari parameter financial distress. Apabila keadaan finansial perusahaan memburuk, maka pemegang saham mampu membuat keputusan melalui rapat untuk mengganti manajer perusahaan. Karena buruknya pengelolaan finansial akan terefleksi pada kualitas kinerja pihak manajemen sehingga proses pergantian tersebut berdampak pada kredibilitasnya di dunia tenaga kerja (Pramudita, 2012). Dengan demikian, guna mencegah kejadian tersebut pihak manajemen menetapkan laba sebagai parameter evaluasi kinerja melalui implementasi konservatisme akuntansi. Karena apabila tingkat kesulitan finansial semakin kompleks, pihak manajemen akan meningkatkan penerapan konservatisme akuntansi, dan situasi tersebut berlaku sebaliknya. Oleh sebab itu, hipotesis yang dapat diformulasikan yakni:

$\mathrm{H}_{4}$ : variabel financial distress berdampak pada moderasi kepemilikan manajerial untuk menerapkan konservatisme akuntansi 


\section{Financial Distress Memoderasi Pengaruh Risiko Litigasi terhadap Konservatisme Akuntansi}

Tingkat risiko ligitasi dapat diestimasikan melalui evaluasi parameter financial distress. Buruknya keadaan finansial perusahaan berdampak pada tingkat risiko ligitasi karena dihadapkan pada tuntutan ke ranah hukum apabila tidak dapat memenuhi hak dari pihak berkepentingan. Perusahaan perlu memitigasi dan menganalisis risiko penyebab kebangkrutan guna mengetahui potensi tersebut sejak dini. Untuk mengantisipasi hal tersebut, perusahaan didorong untuk mengimplementasikan konservatisme akuntansi agar menstimulus pihak manajemen melakukan pengelolaan dengan penuh tanggung jawab guna meminimalisir perselisihan antar pihak berkepentingan, penyampaian kondisi finansial secara transparan, dan merencanakan pengembangan dimasa mendatang secara akurat (Zuhriyah, 2014). Oleh sebab itu, hipotesis yang dapat diformulasikan yaitu:

$\mathrm{H}_{5}$ : variabel financial distress berdampak pada moderasi risiko litigasi untuk mengimplemetasikan konservatisme akuntansi

\section{Financial Distress Memoderasi Pengaruh Leverage terhadap Konservatisme Akuntansi}

Tingkat leverage dapat diestimasikan melalui penilaian parameter financial distress. Keadaan finansial perusahaan mencerminkan kapasitasnya dalam melakukan pembayaran utang. Apabila perusahaan mengalami krisis finansial yang parah, maka menyebabkan peningkatan leverage sehingga berdampak pada kelangsungan operasional bisnisnya. Untuk mencegah hal tersebut, perusahaan distimulus untuk mengimplementasikan konservatisme akuntansi agar pihak manajemen mengelolanya dengan baik serta mampu memitigasi risiko yang dihadapi perusahaan (Sugiarto, 2017). Oleh sebab itu, penerapan konservatisme akuntansi dapat dimanfaatkan guna mengatasi risiko permasalahan utang, mengalokasikan dana cadangan, dan tetap eksis dalam memperoleh kepercayaan dari para investor dan kreditur. Dengan demikian, hipotesis yang dapat diformulasikan yakni:

$\mathrm{H}_{6}$ : variabel financial distress berdampak pada moderasi leverage untuk menerapkan konservatisme akuntansi.

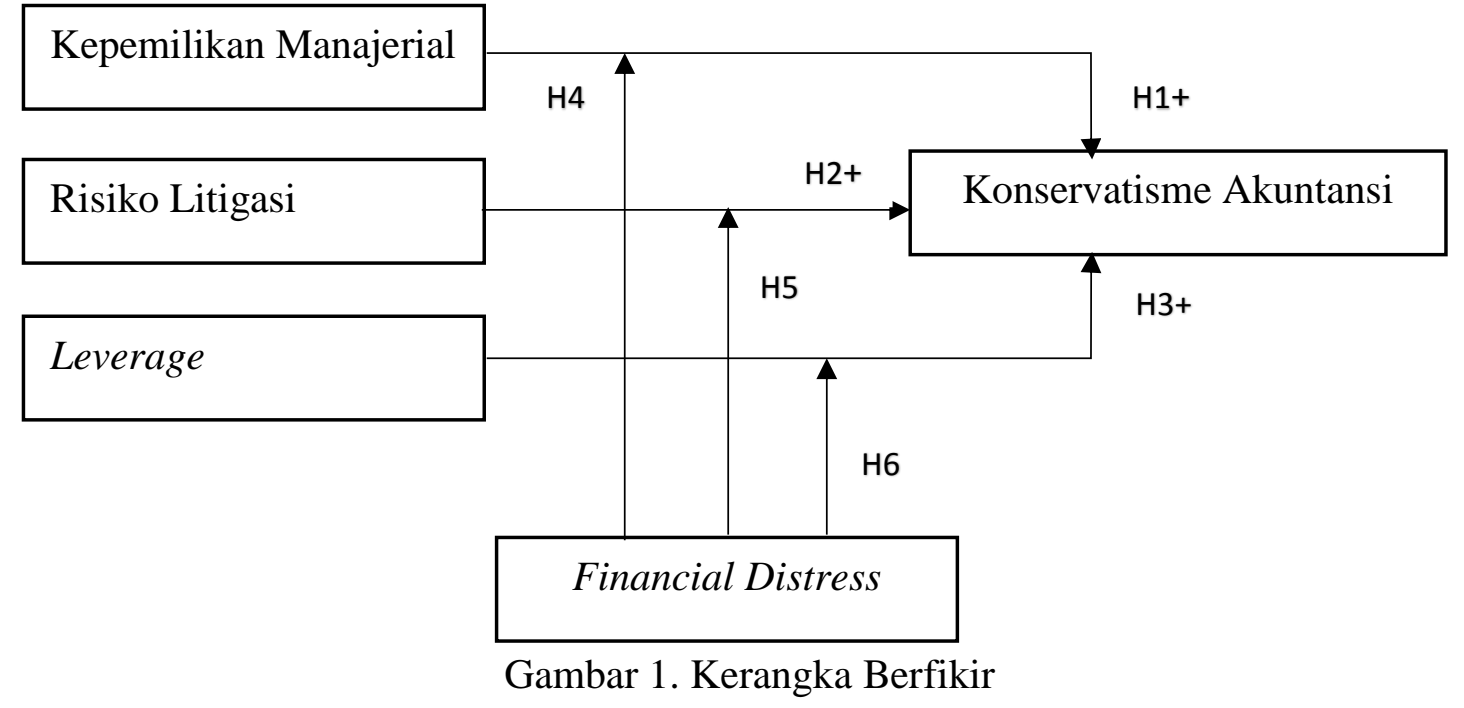

Sumber: Data yang diolah, 2021 


\section{METODE}

Sebanyak 182 perusahaan manufaktur yang teregistrasi di BEI untuk periode 20182020 sebagai populasi yang diobservasi. Sebanyak 72 sampel perusahaan yang memenuhi persyaratan dari total populasi dan dipilih menggunakan pendekatan purposive sampling.

HASIL

Tabel 1. Hasil Analisis Statistik Deskriptif Variabel Kepemilikan Manajerial, Risiko Litigasi, Leverage, Financial Distress dan Konservatisme Akuntansi

\section{Descriptive Statistics}

\begin{tabular}{|l|r|r|r|r|r|}
\hline & $\mathrm{N}$ & Minimum & Maximum & Mean & Std. Deviation \\
\hline KONSERV & 72 & 1.06 & 7.80 & 3.1312 & 1.58082 \\
KEPMEN & 72 & .00 & .85 & .1915 & .23654 \\
RISLIT & 72 & .00 & 1.74 & .6699 & .33937 \\
LEV & 72 & .00 & 1.97 & .7072 & .45951 \\
FIN & 72 & .53 & 7.58 & 3.3479 & 1.71905 \\
& & & & & \\
Valid N (listwise) & 72 & & & & \\
\hline
\end{tabular}

Sumber: Output SPSS 25, 2021

Hasil dari tabel diatas menunjukan bahwa nilai rata-rata yang dihasilkan oleh variabel kepemilikan manajerial lebih kecil dari standar deviasi deviasi yang berarti bahwa data sampel untuk variabel kepemilikan manajerial tidak jauh berbeda sehingga sabran data untuk variabel tersebut besar. Sedangkan nilai rata-rata yang dihasilkan variabel risiko litigasi, leverage, financial distress dan konservatisme akuntansi lebih besar dari standar deviasi yang berarti bahwa sabran data untuk variabel tersebut kecil.

\section{Uji Asumsi Klasik}

\section{Tabel 2. Hasil Uji Normalitas One-Sample Kolmogrov-Smirnov Test}

\begin{tabular}{|l|l|r|}
\hline \multicolumn{2}{|l|}{} & Unstandardized Residual \\
\hline Normal Parameters a.b & Mean & 72 \\
& Std. Deviation & .0000000 \\
Most Extreme Differences & Absolute & 1.38679119 \\
& Positive & .095 \\
& Negative & .095 \\
Test Statistic & -.045 \\
Asymp. Sig. (2-tailed) & .095 \\
\hline $\begin{array}{l}\text { a. Test distribution is Normal } \\
\text { b. Calculated from data } \\
\text { c. Liliefors Significance Correction }\end{array}$ & $.178^{c}$ \\
\hline
\end{tabular}

Sumber: Output SPSS 25, 2021 
Owner: Riset \& Jurnal Akuntansi

e-ISSN : 2548-9224 |p-ISSN : 2548-7507

Volume 6 Nomor 1, Januari 2022

DOI : https://doi.org/10.33395/owner.v6i1.719

Hasil uji ini menunjukan nilai sebesar 0,178, yang berarti hasil tersebut lebih besar dari 0,05 dan menunjukan data tersebut dapat berdistribusi normal.

Tabel 3. Hasil Uji Multikolinieritas

Coefficients $^{\mathrm{a}}$

\begin{tabular}{|c|c|c|c|c|c|c|c|}
\hline \multirow[b]{2}{*}{ Model } & \multicolumn{2}{|c|}{$\begin{array}{c}\text { Unstandardized } \\
\text { Coefficients }\end{array}$} & \multirow{2}{*}{$\begin{array}{c}\begin{array}{c}\text { Standardized } \\
\text { Coefficients }\end{array} \\
\text { Beta }\end{array}$} & \multirow[b]{2}{*}{$\mathrm{T}$} & \multirow[b]{2}{*}{ Sig. } & \multicolumn{2}{|c|}{$\begin{array}{c}\text { Collinearity } \\
\text { Statistics }\end{array}$} \\
\hline & B & $\begin{array}{l}\text { Std. } \\
\text { Error }\end{array}$ & & & & Tolerance & VIF \\
\hline 1 (Constant) & 1.888 & .683 & & 2.762 & .007 & & \\
\hline KEPMEN & -1.309 & .743 & -.196 & -1.761 & .083 & .929 & 1.076 \\
\hline RISLIT & -.427 & 697 & -.092 & -.612 & .542 & .513 & 1.950 \\
\hline LEV & .457 & .509 & .133 & .898 & .372 & .524 & 1.907 \\
\hline FIN & .435 & .110 & .473 & 3.939 & .000 & .796 & 1.258 \\
\hline
\end{tabular}

a. Dependent Variable: KONSERV

Sumber: Output SPSS 25, 2021

Uji multikolonieritas menunjukan nilai Tolerance $>0,10$ dan nilai VIF $<10$ sehingga pada variabel independen tidak terdapat adanya masalah multikolonieritas.

Tabel 4. Hasil Uji Heteroskedastisitas

Coefficients $^{\mathrm{a}}$

\begin{tabular}{|c|c|c|c|c|c|}
\hline \multirow[t]{2}{*}{ Model } & \multicolumn{2}{|c|}{$\begin{array}{l}\text { Unstandardized } \\
\text { Coefficients }\end{array}$} & $\begin{array}{l}\text { Standardized } \\
\text { Coefficients }\end{array}$ & \multirow[t]{2}{*}{$\mathrm{t}$} & \multirow[t]{2}{*}{ Sig. } \\
\hline & $B$ & Std. Error & Beta & & \\
\hline (Constant) & -1.985 & 1.003 & & $1979^{-}$ & .052 \\
\hline KEPMEN & -1.768 & 1.090 & -.199 & $1.621^{-}$ & .110 \\
\hline RISLIT & -1.345 & 1.023 & -.217 & $1315^{-}$ & .193 \\
\hline LEV & .354 & .747 & .077 & .474 & .637 \\
\hline FIN & .085 & .162 & .070 & .524 & .602 \\
\hline
\end{tabular}

a. Dependent Variable: LN_RES

Sumber: Output SPSS 25, 2021

Uji heteroskedastisitas menggunakan uji park, hasil yang dimiliki bahwa masingmasing variabel tingkat signifikansi lebih besar dari 0,05 atau 5\%. 
Owner: Riset \& Jurnal Akuntansi

e-ISSN : 2548-9224 |p-ISSN : 2548-7507

Volume 6 Nomor 1, Januari 2022

DOI : https://doi.org/10.33395/owner.v6i1.719

Tabel 5. Hasil Uji Autokorelasi Durbin Watson

Model Summary

\begin{tabular}{|l|l|l|l|l|l|}
\hline Model & $R$ & $R$ Square & $\begin{array}{l}\text { Adjusted R } \\
\text { Square }\end{array}$ & $\begin{array}{l}\text { Std. Error of } \\
\text { the Estimate }\end{array}$ & $\begin{array}{l}\text { Durbin } \\
\text { Watson }\end{array}$ \\
\hline 1 & $.480^{\mathrm{a}}$ & .230 & .184 & 1.42759 & 2.073 \\
\hline
\end{tabular}

a. Predictors: (Constant), FIN, KEPMEN, LEV, RISLIT

b. Dependent Variabel: KONSERV

Sumber: Output SPSS 25, 2021

Hasil uji autokorelasi dengan durbin watson memiliki nilai $D W$ sebesar 2,073 yang berarti lebih besar dari batas atas (du) 1,7366 dan kurang dari 4-1,7366 (4-du), maka dapat disimpulkan bahwa tidak terdapat gejala autokorelasi pada model regresi.

\section{Uji Hipotesis (Uji Selisih Mutlak)}

\section{Tabel 6. Hasil Uji Selisih Mutlak}

\section{Coefficients $^{a}$}

\begin{tabular}{|c|c|c|c|c|c|c|c|}
\hline \multirow{2}{*}{ Mod } & & \multicolumn{2}{|c|}{$\begin{array}{l}\text { Unstandardized } \\
\text { Coefficient }\end{array}$} & \multicolumn{2}{|c|}{$\begin{array}{l}\text { Standardized } \\
\text { Coefficient }\end{array}$} & & \multirow{2}{*}{ kesimpulan } \\
\hline & & $B$ & Std. Error & Beta & $T$ & Sig. & \\
\hline 1 & $\begin{array}{l}\text { (Constan) } \\
\text { Zscore: KEPMEN } \\
\text { Zcore: RISLIT } \\
\text { Zscore: LEV } \\
\text { ABSZKEPMEN_FIN } \\
\text { ABSZRISLIT_FIN } \\
\text { ABSZLEV_FIN }\end{array}$ & $\begin{array}{r}2.841 \\
-.311 \\
-.735 \\
2.228 \\
.209 \\
.614 \\
-.248\end{array}$ & $\begin{array}{l}.345 \\
.233 \\
.968 \\
.994 \\
.317 \\
1.071 \\
1.091\end{array}$ & $\begin{array}{r}-.118 \\
-.279 \\
.846 \\
.072 \\
.328 \\
-.133\end{array}$ & $\begin{array}{r}8.235 \\
-1.334 \\
-.759 \\
2.241 \\
.660 \\
.573 \\
-.227\end{array}$ & $\begin{array}{l}.000 \\
.187 \\
.450 \\
.028 \\
.512 \\
.568 \\
.821\end{array}$ & $\begin{array}{l}\text { H1 ditolak } \\
\text { H2 ditolak } \\
\text { H3 } \\
\text { diterima } \\
\text { H4 ditolak } \\
\text { H5 ditolak } \\
\text { H6 ditolak }\end{array}$ \\
\hline
\end{tabular}

a.Dependent Variabel: KONSERV

Sumber: Output SPSS 25, 2021

Tabel 7. Hasil Uji Koefisien Determinasi $\left(\mathbf{R}^{2}\right)$

Model Summary

\begin{tabular}{|c|c|c|c|c|}
\hline Model & $\mathrm{R}$ & R Square & $\begin{array}{l}\text { Adjusted R } \\
\text { Square }\end{array}$ & $\begin{array}{l}\text { Std. Error of } \\
\text { the Estimate }\end{array}$ \\
\hline 1 & $.779^{a}$ & .607 & .570 & 1.72567 \\
\hline
\end{tabular}

Sumber: Output SPSS 25, 2021 
Nilai Adjusted $R^{2}$ sebesar 0,570 yang berarti variabel kepemilikan manajerial. Risiko litigasi, leverage, dan financial distress mampu menjelaskan variasi konservatisme akuntansi sebesar 57,0\% sedangkan sisanya 43,0\% dijelaskan oleh variabel lain diluar modal.

\section{PEMBAHASAN}

\section{Pengaruh Kepemilikan Manajerial Terhadap Konservatisme Akuntansi}

Uji-t menampilkan nilai koefisien regresi $=-0,311$, dan nilai $\mathrm{t}$-hitung $=-1,334$ dengan nilai nyata $=0,187$, atau lebih tinggi dari 0,05 . Hasil tersebut diinterpretasikan bahwa variabel kepemilikan manajerial tidak berdampak positif dan substansial pada penerapan konservatisme akuntansi. Dengan demikian, ditolaknya $\mathrm{H}_{1}$ sesuai dengan yang dilaporkan oleh Brilianti (2013); Deviyanti (2012); Sugiarto (2017); Inung et al. (2020); dan Sinambela \& Almilia (2018). Penyebab korelasi tersebut yakni karena pemegang saham kurang terlibat dalam pengambilan keputusan bisnis sehingga pihak manajemen tidak terstimulus untuk menerapkan konservatisme akuntansi perusahaan. Namun bertentangan dengan yang dilaporkan oleh Dewi \& Suryanawa (2014) dan Nugroho (2012) yaitu bahwa variabel kepemilikan manajerial berdampak positif dan substansial pada implementasi konservatisme akuntansi.

\section{Pengaruh Risiko Litigasi Terhadap Konservatisme Akuntansi}

Uji-t memperlihatkan nilai koefisien regresi $=-0,735$, dan nilai t-hitung $=-0,759$ dengan nilai nyata $=0,450$, atau relatif lebih besar dari 0,05 . Hasil tersebut bermakna bahwa variabel risiko litigasi berdampak negatif dan tidak substansial pada penerapan konservatisme akuntansi. Oleh sebab itu, ditolaknya $\mathrm{H}_{2}$ sesuai dengan yang dilaporkan oleh Dewi et al. (2014); Maulana (2017), Putri (2017) dan Sinambela \& Almilia (2018); dan Mustikasari et al. (2020). Namun berbeda pandangan dengan Nugroho (2012) dan Zuhriyah (2014) yang mengungkapkan bahwa variabel tersebut berdampak positif dan substansial pada penerapan konservatisme akuntansi.

\section{Pengaruh Leverage terhadap Konservatisme Akuntansi}

Uji-t menampilkan nilai koefisien regresi $=2,228$, dan nilai t-hitung $=2,241$ dengan nilai nyata $=0,028$, atau lebih rendah dari 0,05 . Hasil tersebut diartikan bahwa variabel leverage mempunyai dampak positif dan substansial pada implementasi konservatisme akuntansi. Oleh karena itu, diterimanya $\mathrm{H}_{3}$ sesuai dengan studi dari Deviyanti (2012); Sugiarto (2017); dan Inung et al. (2020). Tingginya tingkat utang dari perusahaan, menstimulus pihak manajemen untuk mengimplementasikan konservatisme akuntansi guna keberlangsungan operasional bisnisnya, dan pengelolaannya. Namun bertolak belakang dengan riset Brilianti (2013); Dewi et al. (2014), Maulana (2017), Noviantari \& Ratnadi, 2015; Putri (2017); Putri et al. (2020) yang menunjukan bahwa variabel tersebut berdampak negatif dan tidak signifikan pada penerapan konservatisme akuntansi.

\section{Financial Distress Memoderasi Pengaruh Kepemilikan Manajerial Terhadap Konservatisme Akuntansi}

Hasil uji-t didapatkan nilai koefisien regresi $=0,209$, dan nilai t-hitung $=0,660$ dengan nilai nyata $=0,512$, atau relatif lebih tinggi dari 0,05 . Interpretasi hasil tersebut bahwa variabel kepemilikan manajerial tidak dapat dimoderasi oleh financial distress untuk menerapkan konservatisme akuntansi, sehingga ditolaknya $\mathrm{H}_{4}$. Hal tersebut 
membuktikan bahwa tinggi rendahnya variabel moderasi tersebut tidak berdampak substansial pada kepemilikan manajerial guna menstimulus penerapan pengelolaan finansial tersebut meskipun kondisinya tidak sedang stabil.

\section{Financial Distress Memoderasi Pengaruh Risiko Litigasi Terhadap Konservatisme Akuntansi}

Hasil uji-t didapatkan nilai koefisien regresi $=-0,614$, dan nilai t-hitung $=0,573$ dengan nilai nyata $=0,568$, atau relatif lebih tinggi dari 0,05 . Interpretasi hasil tersebut bahwa variabel risiko litigasi tidak mampu dimoderasi oleh financial distress guna mengimplemetasikan konservatisme akuntansi, sehingga ditolaknya $\mathrm{H}_{5}$. Hal tersebut membuktikan bahwa tinggi rendahnya variabel moderasi tersebut tidak mempunyai dampak yang substansial pada risiko litigasi guna mendorong penerapan pengelolaan finansial tersebut meskipun mengalami ketidakstabilan bisnis dan finansial.

\section{Financial Distress Memoderasi Pengaruh Leverage Terhadap Konservatisme Akuntansi}

Hasil uji-t diperoleh nilai koefisien regresi $=-0,248$, dan nilai t-hitung $=-0,227$ dengan nilai nyata $=0,821$, atau jauh lebih tinggi dari 0,05 . Interpretasi hasil tersebut bahwa variabel leverage tidak dimoderasi oleh financial distress guna mengimplemetasikan konservatisme akuntansi, sehingga ditolaknya $\mathrm{H}_{6}$. Hal tersebut menunjukkan bahwa tinggi rendahnya variabel moderasi tersebut tidak berdampak substansial pada leverage guna menstimulus implementasi pengelolaan finansial tersebut meskipun perusahan dalam keadaan finansial yang tidak baik.

\section{KESIMPULAN}

Hasil studi membuktikan bahwa mayoritas perusahaan yang teregistrasi di BEI untuk periode 2018-2020 belum mengimplementasikan konservatisme akuntansi, dan digolongkan rendah dengan nilai 3,1312. Oleh sebab itu, stimulus penerapan konservatisme akuntansi tersebut perlu dilaksanakan guna menurunkan asimetri informasi antara pihak berkepentingan, dan mereduksi anggaran agensi.

\section{REFERENSI}

Brilianti, D. P. (2013). Accounting Analysis Journal. 2(3), 268-275.

Deviyanti, D. A. (2012). Analisis Faktor-faktor yang Mempengaruhi Penerapan Konservatisme Akuntansi. Journal of Accounting, 4.

Dewi, L. P. K., Herawati, N. T. , \& Sinarwati, N. K. (2014). Faktor-Faktor Yang Berpengaruh Terhadap Konservatisme Akuntansi Pada Perusahaan Manufaktur Di Bei. E-Journal S1 Ak Universitas Pendidikan Ganesha, 2(1).

Dewi, N. K. S. L., \& Suryanawa, I. K. (2014). Pengaruh Struktur Kepemilikan Manajerial, Leverage Dan Financial Distress Terhadap Konservatisme Akuntansi. E-Jurnal Akuntansi Universitas Udayana, 7(1).

Fahmi, I. (2011). Analisis Laporan Keuangan. Alfabeta.

Fatmawati, N. (2020). Pengaruh Debt Covenant, Financial Distress, dan Litigation Risk pada Konservaisme Akuntansi dengan Institutional Ownership sebagai Variabel 
Moderating. Skripsi.

Inung, W., Natali, Y., \& Farid, A. (2020). Determinant Analysis in Accounting Conservatism. Russian Journal of Agricultural and Socio-Economic Sciences, 108(12), 19-26. https://doi.org/10.18551/rjoas.2020-12.03

Jensen, C., \& Meckling, H. (1976). Theory Of The Firm: Managerial Behavior, Agency Costs And Ownership Structure I. Introduction and summary In this paper WC draw on recent progress in the theory of ( 1 ) property rights, firm. In addition to tying together elements of the theory of e. 3, 305-360.

Maulana, D. A. (2017). Pengaruh Risiko Litigasi, Leverage, Ukuran Perusahaan Terhadap Tingkat Konservatisme Akuntansi Pada Perusahaan Pertambangan. Artikel Ilmiah.

Mohammed, N. F., Ahmed, K., \& Ji, X. D. (2017). Accounting Conservatism, Corporate Governance and Political Connections. Asian Review Of Accounting, 25(2), 288-318. Https://Doi.Org/10.1108/ARA-04-2016-0041

Mustikasari, Y., Titisari, K. H., \& Wijayanti, A. (2020). The Effect Of Litigation Risk On Accounting Conservatism, Leverage \& Managerial Ownership As Moderation. Jurnal Akuntansi, Audit Dan Sistem Informasi Akuntansi, 4 No.1.

Noviantari, N. W., \& Ratnadi, N. M. D. (2015). Pengaruh Financial Distress, Ukuran Perusahaan, Dan Leverage Pada Konservatisme Akuntansi. E-Jurnal Akuntansi, 11(3).

Nugroho, D. A. (2012). Pengaruh Struktur Kepemilikan Manajerial, Debt Covenant, Tingkat Kesulitan Keuangan Perusahaan, Dan Risiko Litigasi Terhadap Konservatisme Akuntansi (Studi Empiris pada Perusahaan Manufaktur yang terdaftar di BEI Tahun 2008-2010). Skripsi, 1 .

Pramudita, N. (2012). Pengaruh Tingkat Kesulitan Keuangan Dan Tingkat Utang Terhadap Konservatisme Akuntansi Pada Perusahaan Manufaktur Di Bei. Jurnal Ilmiah Mahasiswa Akuntansi, 1(2), 1-6.

Pratanda, S. radyasinta, \& Kusmuriyanto. (2014). Konservatisme Akuntansi, Good Corporate Governance Dan Pengungkapan Corporate Social Responsibility Pada Earnings Response Coefficient. Accounting Analysis Journal, 3(2), 255-263.

Putri, A. G. (2017). Pengaruh Kesulitan Keuangan, Risiko Litigasi, dan Leverage terhadap Konservatisme Akuntansi. JOM Fekon, 4.

Putri, W. W. R., Tartilla, N., \& Pamungkas, M. N. (2020). Analysis Of The Factors That Affect The Company'S Accounting Conservatism. The Accounting Journal Of Binaniaga, 5(2), 101. Https://Doi.Org/10.33062/Ajb.V5i2.391

Riahi, A., \& Belkaoui. (2001). Teori akuntansi buku 2. Salemba Empat.

Risdiyani, F., \& Kusmuriyanto. (2015). Analisis Faktor-Faktor Yang Mempengaruhi Penerapan Konservatisme Akuntansi. Accounting Analysis Journal, 4(3), 1-10. https://doi.org/10.15294/aaj.v4i3.8305

Savitri, E. (2016). Konservatisme Akuntansi Cara Pengukuran, Tinjauan Empiris dan Faktor-faktor yang Mempengaruhinya. Pustaka Sahila Yogyakarta. 
Sholikhah, Z. (2020). Peran Intensitas Modal Dalam Memoderasi Kepemilikan Manajerial , Investment Opportunity Set ( IOS ), Dan Growth Opportunity Terhadap Konservatisme Akuntansi. Skripsi.

Sinambela, M. O. E., \& Almilia, L. S. (2018). Faktor-Faktor Yang Mempengaruhi Konservatisme Akuntansi. 21(2), 289-312.

Sugiarto, H. V. S. (2017). Pengaruh Financial Distress, Leverage, Investment Opportunity Set (IOS) dan Kepemilikan Manajerial Terhadap Konservatisme Akuntansi. Skripsi.

Sulastri, S., \& Anna, Y. D. (2018). Pengaruh Financial Distress Dan Leverage Terhadap Konservatisme Akuntansi. Akuisisi: Jurnal Akuntansi, 14(1), 59-69. https://doi.org/10.24127/akuisisi.v14i1.251

Wulandari, I., Andreas, \& Ilham, E. (2014). Pengaruh Struktur Kepemilikan Manajerial, Debt Covenant, dan Growth Opportunities Terhadap Konservatisme Akuntansi. JOM Fekon, 1(hal 140), 43. http://www.springer.com/series/15440\%0Apapers://ae99785b2213-416d-aa7e-3a12880cc9b9/Paper/p18311

Yuliarti, D., \& Yanto, H. (2017). The Effect Of Leverage, Firm Size, Managerial Ownership, Size Of Board Commissioners And Profitability To Accounting Conservatism. Accounting Analysis Journal, 6(2), 173-184. Https://Doi.Org/10.15294/Aaj.V6i2.16675

Zuhriyah, E. A. (2014). “ Konvergensi Ifrs, Leverage, Financial Distress, Litigation Dalam Kaitannya Dengan Konservatisme Akuntansi " Studi Empiris Pada Perusahaan Sektor Transportasi yang Terdaftar di BEI Periode 2010-2014. 204-219. 